\title{
RESPONSE TO PETER THOMPSON INTERVIEW, FROM MICHAEL ADAMS
}

\author{
Transforming Cultures eJ ournal, \\ Vol. 3 No 1, February 2008 \\ http:// epress.lib.uts.edu.au/journals/TfC
}

\section{Michael Adams ${ }^{1}$}

In the following comments, I have chosen three broad themes raised by the paper, "From Movement to Management: Aboriginal assertion, government and environmentalist responses and some ways forward regarding conservation and social justice" and engaged with them in terms of the paper itself, their relationship to my own work, and how they illuminate the symposium questions, including comparisons with India.

\section{Positionality and power}

The topic of Peter's interview is quite a challenging issue to discuss, where Peter analyses the divergent views of two groups of people from outside both groups. His long history of involvement gives a very good context, but also positions him in particular ways.

Because of this, I think it's important to reflect on positionality - Peter's position relative to the people, processes and things he is engaging with in this issue. This is clearly not going to be 'fixed': some of the time Peter is a member of the Board of Management he discusses, and he maintains and environmental activist role as well as an Aboriginal social justice activist role. Positionality is also significant for the subjects of the paper, as well as the author. Indigenous people have positions both as embedded community members and as employees of nature conservation agencies, a fact which

\footnotetext{
${ }^{1}$ Michael has carried out collaborative research with Aboriginal and Torres Strait Islander peoples in numerous contexts, including 'remote' Aboriginal and Islander communities (Cape York), and Aboriginal people from regional centres (Townsville, Bowen, Wollongong) and urban areas (Sydney). He has 20 years employment and consultancy experience with Aboriginal organisations across a spectrum of responsibilities, as well as professional roles in environment NGOs and state agencies.
} 
causes significant consternation for bureaucrats attempting to support processes of 'disinterested' decision-making.

Government conservation departments have an interesting relationship with activists, where many environmental activists regularly move employment between NGOs and the bureaucracy, but social justice activists are often seen as a problem to be contained. My own current experience as an academic and researcher, after a history in NGOs, conservation bureaucracies and Aboriginal organisations, leads me to broadly similar conclusions as Peter about joint-management. After an initially promising start, the NSW Government is moving away from this potentially innovative approach, and going back to conservation-as-usual, with Aboriginal people as stakeholders rather than rightsholders. Government generally has trouble relinquishing power, as Peter points out in the debates about decisions of the Mutawintji Board of Management.

In India, there are simultaneously issues about Indigenous and local access and management of protected areas, and the role of scientific enquiry in these areas. Mahesh Rangarajan and others (Madhusudan et al 2006) reveal systematic and arbitrary restrictions by Indian wildlife authorities on external research carried out in national parks: 'scientific research, in effect, has been deemed an undesirable activity’ (p. 1018). There is no indication that this happens in Australia in ecological research, but it may conceivably happen in issues of social and political research, particularly in perceived sensitive locations such as Uluru-Kata Tjuta National Park. The central issue is the fact that governments and their departments are able to exert this sort of control.

\section{Country and productivity}

There is a brief hint of a very interesting element of the discussion, focusing around 'productivity' of country. I think this would be interesting to explore further in terms of conservation agency/conservationist ideas, pastoralists' ideas and Wiimpatja ideas, and the overlaps and connections between those (e.g. Wiimpatja pastoralists).

Western conservation approaches have generally strictly divided 'productive' and 'conservation' tenures, with one outcome being that 'productive' tenures usually have no connection to conservation goals. Relatively recent ideas about the 'ecosystem services' provided by conservation tenures have started to change that. Indigenous 
understandings of country usefully challenge both the production/conservation dichotomy, in that country is obviously productive of all sorts of things useful to Aboriginal people (and others); and, as Peter points out, the natural heritage/cultural heritage dichotomy, in that culture is better reflected (and protected) by an approach focusing on country rather than sites .

Similarly, further exploration of the relationship between national park boundaries, reserve design and Wiimpatja notions of country would be very interesting. These issues are important for Aboriginal people throughout Australia, as the boundaries of land regained under joint management or land rights legislation reflect Western tenure arrangements and not the dimensions of Aboriginal country. Ironically, national parks agencies recognise that it would be much more effective to manage nature on a 'country' basis (catchments, biogeographic regions, or landscapes) rather than the tenure arrangements created by Western property divisions (for theory, see Forman 1995, for principles and practice, see Worboys, Lockwood and De Lacy 2001). The critical difference between Indigenous and national park views on this is the significance of local people: in park planning they are relevant only as generic 'stakeholders'; in Indigenous laws they are central, expressed in the phrase 'the right to speak for country' (see Arthur 1996).

Again, Indian experience is very interesting in this area. Productivity of Indian protected areas is indicated by extrapolated figures by Saberwal, Rangarajan and Kothari (2001, p 72); ' there are at least three million people living inside PAs, and several million more using them from adjacent settlements'. The use of this productivity also highlights another aspect, 'the enormous knowledge of ecosystems and wildlife that India's local communities had, and in many cases still have' (ibid. p. 74). This is of course reflected in Australian Indigenous knowledge (see, for instance Langton 1998, Baker, Davies and Young 2001). Central government agencies in both India and Australia persistently ignore this knowledge, or if they do acknowledge it, often use it without context or permission, and in very limited ways.

\section{Some ways forward}

In many ways this is the most important part, where the history and processes are brought into engagement with ways to reach better outcomes. 
In terms of Peter's discussion, achieving a balance between recounting a history of negative relationships and mistrust, and a focus on getting 'practiced in partnerships' is important. Identifying the unproductive behaviour, rather than labelling the (assumed) intent is a useful strategy. A major challenge for park managers is the process of reconstructing their foundational myths for conservation, and Peter indicates there is positive change here. This is often particularly difficult, as managers are presented with conflicting positions from their experience on the ground and their communications with Head Office. Learning from Aboriginal people (even the acknowledgement that there is something to learn from Aboriginal people!) is fundamental.

For many Aboriginal people, there are not any tensions around their social goals and conservation goals: there are perceived tensions from conservationists. In northern and central Australia there are very large areas of land managed by Aboriginal people, both as Aboriginal freehold land and as Indigenous Protected Areas

(see <http://www.environment.gov.au/indigenous/ipa/index.html>), with very significant outcomes for conservation (see for example, Bowman and Prior 2004). The last two decades have seen a significant increase in jointly-managed national parks in Australia, under a variety of arrangements, but potentially no real advance in systems of governance or real outcomes for Aboriginal people, except in isolated situations. In NSW, as the first and longest colonised region, assumptions about Aboriginality, and the historical roots of the national park system, have to some extent constrained innovation.

An approach which starts to recognise the real, on-ground contribution to healthy land of Aboriginal ways of looking after country, and also starts to critically examine the fundamental mythologies and beliefs underpinning Western conservation, can be the basis for partnerships which start to foreground Aboriginal rights and knowledge. Taking this step could enable Australia to be a real leader in innovative governance for protected areas.

\section{References}

Arthur, J (1996) Aboriginal English, Oxford University Press, Melbourne.

Baker, R, Davies, J., and Young E (eds.) (2001) Working on country: contemporary indigenous management of Australia's lands and coastal regions, Oxford University Press, Melbourne. 
Bowman D.M.J.S.; Prior L.D. (2004) Impact of Aboriginal landscape burning on woody vegetation in Eucalyptus tetrodonta savanna in Arnhem Land, northern Australia , Journal of Biogeography, Vol 31, No 5, pp. 807-817.

Forman, D. (1995) Land Mosaics, Cambridge University Press, Cambridge.

Langton, M. (1998) Burning Questions: Emerging Environmental Issues for Indigenous Peoples in Northern Australia, Centre for Indigenous Natural and Cultural Resource Management, Darwin.

Madhusudan, MD, Shankar, K., Kumar, A., Mishra, C., Sinha, A., Arthur, R., Datta, A., Rangarajan, M., Chellam, R., Shahabuddin, G., Sankaran, R., Singh, M., Ramakrishnan, U., Rajan, P.D. (2006) Science in the wilderness: the predicament of scientific research in India's wildlife reserves, Current Science, Vol 91, No 8, pp1015-1019.

Saberwal, V, Rangarajan, M., Kothari, A. (2001) People, Parks and Wildlife: Towards Coexistence, Orient Longman, Hyderabad.

Worboys, G., Lockwood, M. and De Lacy, T. (2001) Protected Area Management: Principles and Practice, Oxford University Press, Melbourne. 